\title{
Calcilobes wangshenghaii n. gen., n. sp., microbial constructor of Permian-Triassic boundary microbialites of South China, and its place in microbialite classification
}

\author{
Stephen Kershaw ${ }^{1,2}$ [ $\cdot$ Tingshan Zhang ${ }^{3} \cdot{\text { Yue } \mathrm{Li}^{4}}^{4}$
}

Received: 1 July 2021 / Accepted: 3 September 2021 / Published online: 27 September 2021

(C) The Author(s) 2021

\begin{abstract}
Permian-Triassic boundary microbialites (PTBMs) that formed directly after the end-Permian extinction in the South China Block are dominated by one structure, a lobate-form calcium carbonate construction that created extensive very thin (ca. 2-20 m thick) framework biostromes in shallow marine environments, effectively occupying the ecological position of the prior pre-extinction Permian reefs and/or associated carbonates. In the field, vertical sections show the microbialite is dendrolite (branched) and thrombolite (clotted), but because thrombolite may include branched portions, its structure is overall best classed as thrombolite. In the field and in polished blocks, the microbial material appears as dark carbonate embedded in lighter-coloured micritic sediment, where details cannot be seen at that scale. In thin section, in contrast to the largely unaltered micritic matrix, the microbial constructor is preferentially partly to completely recrystallised, but commonly passes gradationally over distances of a few $\mathrm{mm}$ to better-preserved areas comprising 0.1-0.2 $\mathrm{mm}$ diameter uneven blobs of finegrained calcium carbonate (micrite to microsparite). The lobate architecture comprises branches, layers and clusters of blobs ca. 1-20 mm in size, and includes constructed cavities with geopetal sediments, cements and some deposited small shelly fossils. Individual blobs in the matrix may be fortuitous tangential cross sections through margins of accumulated masses, but if separate, may represent building blocks of the masses. The lobate structure is recognised here as a unique microbial taxon and named Calcilobes wangshenghaii n. gen., n. sp. Calcilobes reflects its calcium carbonate composition and lobate form, wangshenghaii for the Chinese geologist (Shenghai Wang) who first detailed this facies in 1994. The structure is interpreted as organically built, and may have begun as separate blobs on the sea floor sediment (that was also composed of micrite but is interpreted as mostly inorganic), by microbial agglutination of micrite. Because of its interpreted original micritic-microsparitic nature, classification as either a calcimicrobe (calcified microbial fossil) or a sedimentary microbial structure is problematic, so $C$. wangshenghaii has uncertain affinity and nature. Calcilobes superficially resembles Renalcis and Tarthinia, which both form small clusters in shallow marine limestones and have similar problems of classification. Nevertheless, Calcilobes framework architecture contrasts both the open branched geometry of Renalcis, and the small tighter masses of Tarthinia, yet it is more similar to Tarthinia than to Renalcis, and may be a modification of Tarthinia, noting that Tarthinia is known from only the Cambrian. Calcilobes thus joins Renalcis, Tarthinia and also Epiphyton (dendritic form) and others, as problematic microbial structures. Calcilobes has not been recognised elsewhere in the geological record and may be unique to the post-end-Permian extinction facies. $C$. wangshenghaii occurs almost exclusively in the South China Block, which lay on the eastern margin of Tethys Ocean during Permian-Triassic boundary times; reasons for its absence in western Tethys, except for comparable fabrics in one site in Iran and another in Turkey, are unknown.
\end{abstract}

Keywords End-Permian extinction $\cdot$ Microbialites $\cdot$ Calcimicrobes $\cdot$ Calcilobes wangshenghaii

Stephen Kershaw

Stephen.kershaw@brunel.ac.uk

1 Department of Life Sciences, Brunel University London, Kingston Lane, Uxbridge UB8 3PH, UK

2 Earth Sciences Department, The Natural History Museum, Cromwell Road, London SW7 5BD, UK
3 School of Geosciences and Technology, Southwest Petroleum University, No. 8 Xindu Road, Xindu District, Chengdu 610500, Sichuan, China

4 State Key Laboratory of Paleobiology and Stratigraphy, Center for Excellence in Life and Paleoenvironment, Nanjing Institute of Geology and Palaeontology, Chinese Academy of Sciences, Nanjing 210008, China 


\section{Introduction and aim}

Microbialite deposits formed directly following the endPermian extinction in shallow marine carbonate environments in Tethys, and constitute a very thin (ca 2-20 m thick) unit of presumed organic origin, for a short period crossing the Permian-Triassic boundary, described in a wide variety of publications (e.g. Ezaki et al. 2003; Baud et al. 2005; Pruss et al. 2006). These Permian-Triassic boundary microbialites (PTBMs) vary in nature in the different parts of Tethys, with notable contrasts between western and eastern Tethys (Kershaw 2015). The South China Block was a distinct small continental mass during that time (Fig. 1), where the microbialite was developed separately from other areas. Although stromatolites are present in some sites (Adachi et al. 2017; Zhang et al. 2020a), the dominant microbial form is a lobate structure not seen in other areas except for one locality in NW Iran (Maaleki-Moghadam et al. 2019) and another in Turkey (SK unpublished observations of newly-processed samples). In South China (Fig. 2), the microbialite has characteristics of both microbially related sediment and calcimicrobes (calcified microbial fossils that may or may not be skeletal in origin), see Figs. 3, 4, 5, 6, 7, 8, described later. However, understanding of the nature of the PTBMs in the South China Block is hampered by extensive recrystallisation, leaving only remnant fabrics in most samples (Fig. 3). Nevertheless, the material commonly has sufficient preservation of a micritic-microsparitic texture to allow recognition that this is likely to be the original fabric (Figs. 4, 5, 6, 7, 8) and detailed examination leads to the conclusion that it is a unique microbial structure in the fossil record, which warrants its own taxon. This study therefore aims to emphasise the distinctness of the South China Block microbialite by establishing a new microbial taxon, which may be limited to the Permian-Triassic interval. Because of copious illustration in the literature of field, polished blocks and thin sections of the lobate fabric, only essential images are presented here, to support the taxonomic treatment and discussion of the nature of the material.

\section{Brief history of study}

The first description of the deposit studied here was by Reinhardt (1988, Pl. 38, Fig. 3), who described its features as ".. patterned Changxing carbonates.. ", thus he regarded it as part of the latest Permian deposits. Reinhardt (1988) attributed the domal upper layers of the structure to embryonic teepees resulting from evaporation at the time of the lowest sea level position of the Phanerozoic Eon.

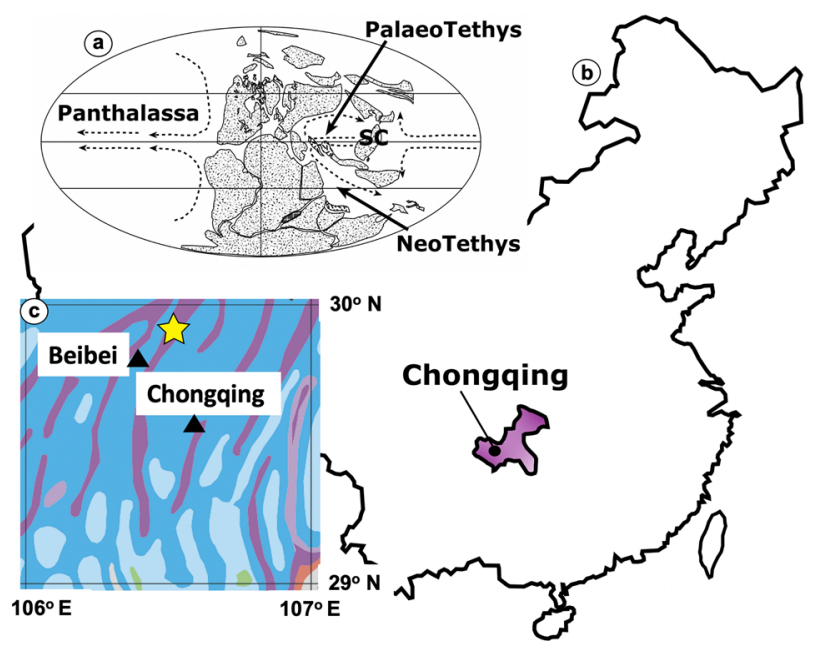

Fig. 1 a Global palaeogeographic reconstruction of the PermianTriassic boundary time, showing South China (SC) Block in eastern Tethys; interpreted ocean circulation shown in dashed arrows. b Map of China showing location of Chongqing SAR, and Chongqing City. c Summary geological map of region around Chongqing City, showing location of Laolongdong (yellow star, see text for coordinates), $30 \mathrm{~km}$ NE from Beibei; purple: Triassic and older rocks, including the Permian-Triassic boundary facies, in folded rocks exposed as ridges on the landscape; dark and light blue: Early and Middle Jurassic rocks, respectively

However, the most significant early study is by Wang et al. (1994) in a Chinese paper that described the deposit in detail and interpreted the structure as fossil soil because of its superficial resemblance to pedogenic forms of caliche profiles (e.g. Esteban and Klappa 1983, Fig. 43). Thus, the structure was referred to by Wang et al. (1994) as a crust developed on the eroded surface of the latest Permian reefs during the lowstand. That interpretation was made prior to general recognition of microbial facies in this interval and a key part of the problem of identification is the pervasive recrystallisation of the fabric. Lehrmann (1999, working in Guizhou) and Kershaw et al. (1999, working in Sichuan and Chongqing) recognised the microbial nature of the deposit, and applied the term "Renalcis-like" in acknowledgement of the lobate micritic rims infilled with sparite, that is commonly observed, which seemed to be consistent with a chambered architecture.

\section{Microbialite main features}

According to the original definition (Burne and Moore 1987): "Microbialites are organosedimentary deposits formed from interaction between benthic microbial communities (BMCs) and detrital or chemical sediments.”. 
Under that broad definition, the microbialite studied here has thrombolite and dendrolite forms because of its clotted and digitate appearance, respectively, in vertical section in outcrops and polished block (mesoscale) views. Kershaw et al. (2007) applied the term digitate dendrolite to PTBMs in Sichuan. However, Riding (2011a) presented a cogent argument that a dendrolitic form seen in vertical section may also be classed as a thrombolite because in transverse section the branched architecture appears as clots on a cut surface. Overall, therefore, these structures within the PTBMs are best described as thrombolites.

Within thrombolites generally in the rock record, the construction may vary; the principal components may be a combination of calcimicrobes (= calcified microbial fossils), clotted micrite (presumed biogenically influenced or controlled (Riding 2011a) and cement. Within calcimicrobes, there are complications of classification, because some calcimicrobes are clearly calcified filaments and sheaths of such organisms as cyanobacteria (e.g. Girvanella, Rivularia) but others are composed of micrite (e.g. Renalcis, Epiphyton, Tarthinia, generally relevant to this study) that are problematic because there are potential alternative mechanisms for their formation. For example, Renalcis has been variously interpreted as a calcimicrobe (Riding 2011b), a calcified biofilm (Stephens and Sumner 2002) and a diagenetic alteration product (Pratt 1984). Furthermore, Lee et al. (2014) drew attention to the similarity between Renalcis and Tarthinia, and noted the possibility that both are diagenetic structures. The PTBMs of the South China Block are composed largely of recrystallised structure that contains evidence of an original micritic form, but demonstrates structure that some authors have called calcimicrobes (e.g. Kershaw et al. 2012), although is actually problematic to precisely classify, with similarity to both Renalcis and Tarthinia, discussed later. The PTBMs occur over a substantial area of the South China Block, on top of the latest Permian deposits (e.g. Xie et al. 2010). Although stromatolites (defined as being layered) occur in some places (Zhang et al. 2020a), the lobate thrombolitic structure is the dominant form.

\section{Systematics and description}

Recognising the unique form presented by the South China PTBM thrombolite, we propose a new taxon to define it.

Phylum, Class, Order and Family: unknown.

Genus: Calcilobes, n. gen.

Etymology: Calcilobes is named for the lobate fabric of the solid (unchambered) micritic-microsparitic structure, made of calcium carbonate.

Type species: Calcilobes wangshenghaii, n. sp.
Diagnosis: Masses of circular to irregularly elliptical blobs of solid micritic-microsparitic calcium carbonate; blobs are 0.1-0.2 $\mathrm{mm}$ in largest dimension, as seen in thin section (Figs. 3, 4, 5, 6). Blobs are mostly amalgamated as a constructed lobate framework of branches, layers and clusters ca. $1-20 \mathrm{~mm}$ in size, enclosing small cavities with geopetal sediments and cements. The lobate framework is accompanied by individual subspherical blobs of the same texture, size and shape, that occur in two locations: (1) as distinct structures surrounded by the carbonate mudstone matrix of the deposit (Figs. 6, 8); and (2) as peloids in geopetal cavities within the lobate framework (Fig. 7), that may have been washed into the cavities. We note that individual blobs in the matrix may be fortuitous tangential cross sections of margins of accumulated masses. Nevertheless, in some samples, these separate blobs show gradation from the un-clotted matrix (Fig. 9), leading to the possibility that there is a genetic relationship between the matrix sediment and the formation of $C$. wangshenghaii, discussed later.

Despite their interpreted original solid texture, blobs are most commonly preserved with micritic-microsparitic outlines up to $0.1 \mathrm{~mm}$ thick $\mathrm{mm}$ thick, and sparite interiors, viewed here as a diagenetic aggrading recrystallisation of the interior, leaving the rim portion as the original, or close to original, texture. In cases of pervasive re-crystallisation, the rim is completely altered to sparite so that the lobate structure is a fully sparitic mass within the enclosing micrite matrix that appears unaltered.

Calcilobes wangshenghaii, n. sp.

Etymology: wangshenghaii is named in memory of Shenghai Wang, of Southwest Petroleum Institute (SWPI), Nanchong, Sichuan, China (that subsequently became Southwest Petroleum University in Chengdu). Shenghai Wang was born on 12 September 1962 in Fengxian, Shanxi Province and later was a PhD student of Prof Jiasong Fan, Beijing, the doyen of Permian reef work in China. Wang subsequently worked in SWPI on a range of petroleum-related projects on Permian reefs in Sichuan and Chongqing. Wang's publication of the first full description of the lobate microbialite was in 1994 when he was 32 years old; however, in October 1995, he sadly died. Descriptions and interpretations presented in this study are thus given in honour of that first account.

Types: NIGP176542, thin section (holotype), NIGP176543, sample from which holotype was made; NIGP176544 thin section (paratype), NIGP176545, sample from which paratype was made. Total 4 specimens, stored at the Nanjing Institute of Geology, Nanjing, China.

Type locality: Holotype and paratype were collected from Laolongdong site, $15 \mathrm{~km}$ NE of Beibei city, Chongqing SAR, South China, (Fig. 1) from upper part of the microbialite at $29^{\circ} 53^{\prime} 26.45^{\prime \prime} \mathrm{N}, 106^{\circ} 30^{\prime} 48.55^{\prime \prime} \mathrm{E}$. The microbialite ranges from latest Permian Hindeodus praeparvus conodont 

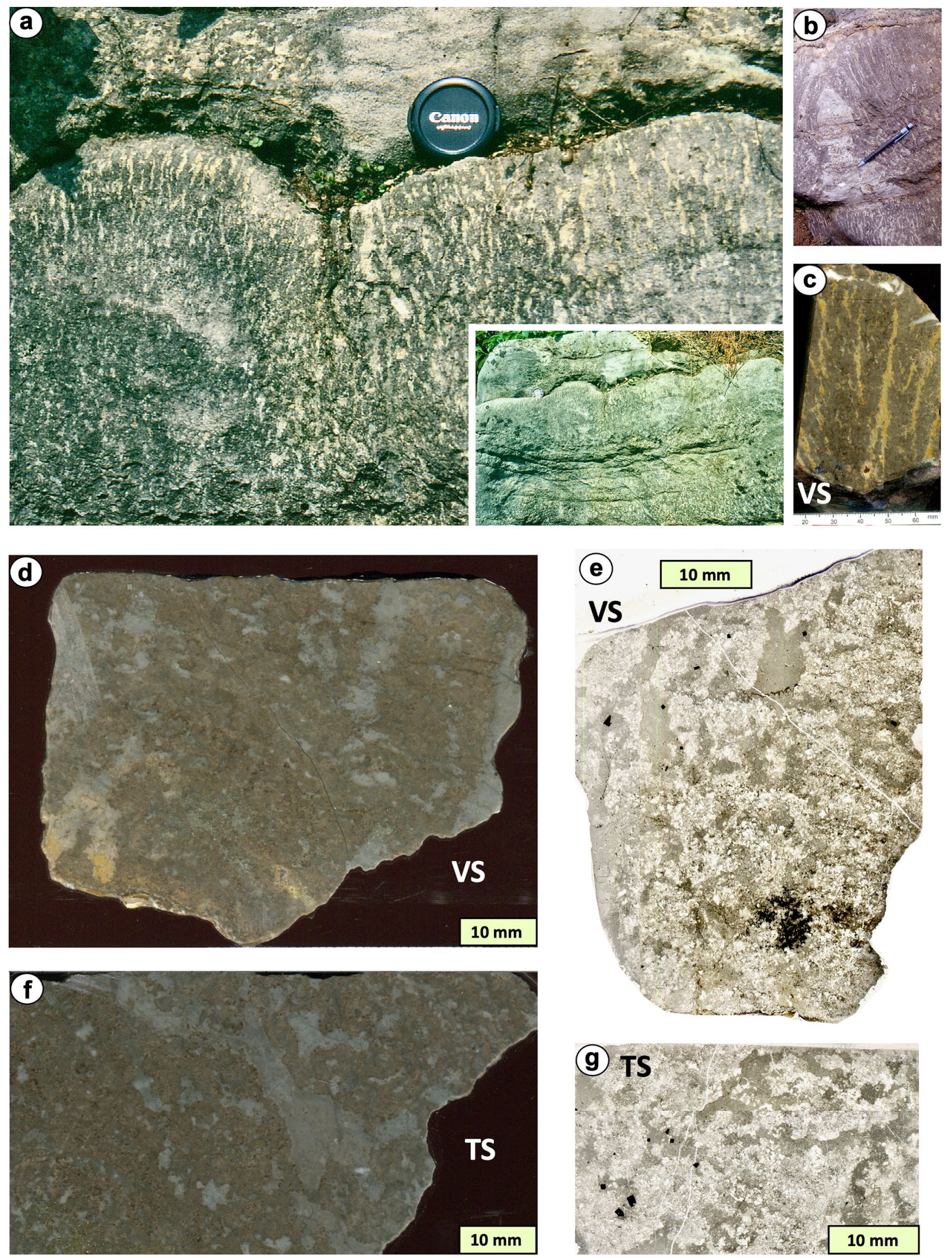
४Fig. 2 Views of Permian-Triassic Boundary Microbialites (PTBMs) at Laolongdong. a, b Field views of vertical sections of PTBM showing digitate and amalgamated structure of the microbialite. Inset in a shows the entire thickness of the microbialite at Laolongdong, with a laminar form in the lower part and domal in the upper part; the main picture is the domal upper part comprising a mixture of digitate and amalgamated structure. c Vertical section of polished block showing common digitate structure. $\mathbf{d}-\mathbf{g}$ Views of holotype and paratype specimens of Calcilobes wangshenghaii n. gen., n. sp, samples that have an amalgamated microbial architecture (see text for description). $\mathbf{d}$, e are the holotype (vertical sections); $\mathbf{d}$ is polished block, e is a scanned thin section. $\mathbf{f}, \mathrm{g}$ are the paratype (transverse sections); $\mathbf{f}$ is polished block, $\mathbf{g}$ is a scanned thin section; in $\mathbf{d}$ and $\mathbf{f}$, dark areas are the microbial structure, grey is intervening micritic sediment; in $\mathbf{e}$ and $\mathbf{g}$, light areas are the microbial structure, dark areas are the intervening sediment

zone to earliest Triassic Hindeodus parvus conodont zone, thus crosses from Palaeozoic into Mesozoic strata. $C$. wangshenghaii holotype and paratype samples are not tied precisely to conodont stratigraphy, but are most likely from a basal Triassic horizon.

Diagnosis: Because Calcilobes is a new genus and $C$. wangshenghaii the only current species, the diagnosis is as above for Calcilobes.

Description: As stated above for the Calcilobes diagnosis, the lobate architecture is embedded in largely unaltered micrite matrix. In some cases, shelly fossils are preserved in the matrix and in cavities within the microbial material (Figs. 4, 5, 7). Microbial margins are in direct contact with enclosing micritic matrix, which in some cases consists of two generations of micritic fill (Fig. 6), recrystallised areas of microbialite are commonly preserved as a thin microsparitic rim with the interior altered to sparite. In few examples, a thin inward-pointing layer of calcite crystals is present (Fig. 6b). Despite its pervasive alteration, ghosts of lobate fabric remain throughout the structure in most cases, allowing its nature to be identified (Fig. 3), in gradational transitions with better-preserved fabric in the same mass (Figs. 4, 5, 6, 7, 8). In extreme re-crystallisation, all internal structures are lost, even the microsparitic rim is replaced by sparite, but the lobate nature of the structure is still recognisable due to its lobate margins, thus forming a cast in normally unaltered micritic matrix. There is sporadic dolomitization of the recrystallised lobate structure and of the adjacent matrix. Overall, $C$. wangshenghaii built layers ca. 10-30 cm thick separated by small breaks, normally obscured by stylolites, but in some cases identified as erosion surfaces (Kershaw et al. 2012). Commonly, the layers are laminar in the lower part of the deposit, but become domed in the upper part, where a digitate form is commonly displayed (Fig. 2).
Remarks: C. wangshenghaii. occurs across a large part of the South China Block (see Xie et al. 2010, fig. 1 for distribution map of the microbialite). Holotype and paratype samples described here are of a partly digitate, partly amalgamated style of growth in the upper portion of the microbialite unit. The appearance of a thin-branched digitate form is the most common view, because most exposures show the structure in vertical section (compare Fig. 2a-c with Fig. 2d). However, Fig. 2f shows the material in transverse section where the amalgamation is well demonstrated. The amalgamated material shows the microbial structure very well. More field, hand specimen, thin section and SEM photographs from this facies are widely published, very good examples of which are in Ezaki et al. (2003, 2008).

C. wangshenghaii also contains ostracods, gastropods and microfossils trapped inside its structure (e.g., Yang et al. 2011), the microfossils are most commonly spherical objects ca $0.01 \mathrm{~mm}$ in diameter (see Kershaw et al., 2012, Fig. 4d). Also, in some places, tiny elongate chambered structures occur, named as "Polybessurus-like fossils" (PLFs) by Zhang et al. (2020b), and similar structures called Gakhumella by Wu et al. (2017). Hughes (2013, Fig. 3) placed Gakhumella in an intertidal to hypersaline environment, contrasting the subtidal setting of the PTBM. In the PTBMs, the structures called PLFs and Gakhumella may be the same fossil. However, these additional components are rare in the lobate fabrics, existing only as fragments that seem to have been deposited via currents on the surface of the microbialite as it grew; they are not components of frame building, so do not contribute to the taxonomic description of the microbialite presented here.

Comparisons with other similar microbial taxa are presented in Fig. 10, comparing C. wangshenghaii with Renalcis and Tarthinia. Renalcis forms small masses of chambered micritic structure with sparite infills; Tarthinia is likewise chambered (Lee et al. 2014) and forms small masses. Although at small scale, there are similarities between $C$. wangshenghaii and Renalcis/Tarthinia, the latter two do not form the complex arrangements that comprise individual blobs and the constructed frameworks with geopetal cavities seen in $C$. wangshenghaii.

\section{Cavities and fills}

The constructed framework of $C$. wangshenghaii has numerous small (up to ca $10 \mathrm{~mm}$ ) internal cavities, interpreted here as constructed as the framework developed. The cavities accumulated five kinds of fill components: 

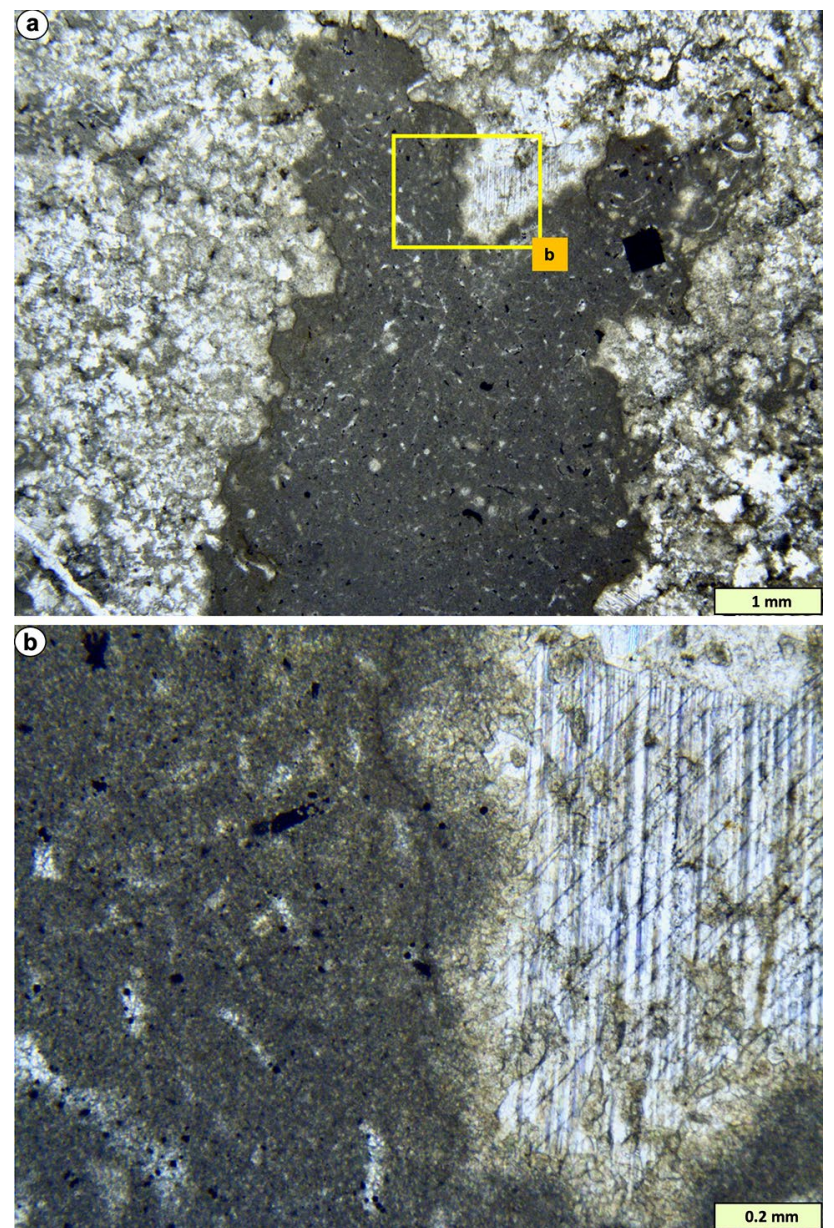

Fig. 3 a, b Views of the holotype of $C$. wangshenghaii (vertical section), showing the typical recrystallised structure of the microbial material, contrasting well-preserved intervening matrix. In $\mathbf{b}$, detail of the recrystallisation shows the margins of the microbial branches are preserved as micrite-microsparite, contrasting the larger sparite crystals in the interior, giving the impression of chambered Renalcislike fabric, yet the structure is clearly recrystallised, considered in the text. The small areas of sparite within the matrix are of uncertain origin; some or all may be recrystallised bioclasts, but may instead be evidence of sponges interpreted by some authors (e.g. Baud et al. 2021; Foster et al. 2019; Friesenbichler et al. 2018) to occupy space between microbial branches

1. Micritic sediment, interpreted as mechanically deposited between branches and in cavities in the framework (Figs. 3, 4, 8);

2. Large peloids that commonly have altered centres, with an identical appearance to the partially altered inner portions of the lobate architecture (Fig. 7);

3. Clotted micrite (well preserved) partially occupying cavity space (Figs. 6, 8, 9);

4. Small peloids filling much of remaining space in cavities (Figs. 6, 8);

5. Sparite cement filling remaining space (Fig. 7).

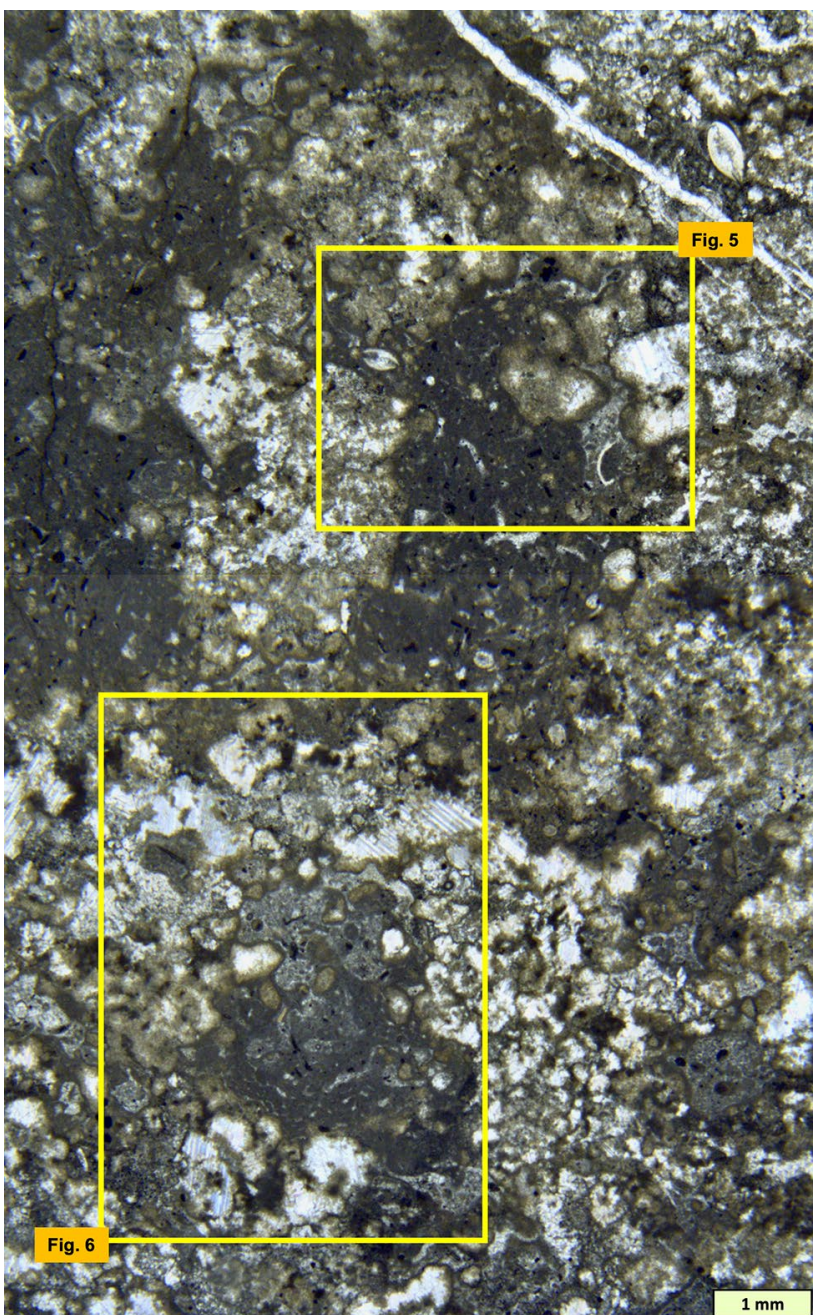

Fig. 4 Vertical section of another part of the holotype of $C$. wangshenghaii showing its amalgamated lobate architecture, with variable preservation. Dark areas between microbial branches are intervening micritic sediment. Boxes show the areas of Figs. 5 and 6

\section{Discussion}

\section{Affinity and comparisons}

Because the original structure of $C$. wangshenghaii is interpreted here to have been a solid mass of fine-grained calcium carbonate, the issue of what process created the structure presents problems. Differences between $\mathrm{Cal}$ cilobes, Renalcis and Tarthinia are shown in Fig. 10. Calcilobes lacks the chambered structure diagnostic of Renalcis and Tarthinia (Riding 2011b). Renalcis and Tarthinia are commonly viewed as calcimicrobes, therefore calcareous fossils, but even this is controversial; as noted earlier, Renalcis, Tarthinia and Epiphyton may be diagenetic structures (Pratt 1984; Stephens and Sumner 
2002; Lee et al. 2014). Although there is some similarity with the micritic branching structure of Tarthinia (Lee et al. 2014), Calcilobes is not the same as other microbial forms. There is sufficient difference from the small chambered masses of Tarthinia that the PTBM form cannot be attributed to it (Fig. 10). Wu et al. (2014) compared the recrystallized individual blobs described in this study with modern cyanobacterium Microcystis that forms blooms in modern freshwater environments, where masses of the cyanobacterium develop. Microcystis is planktonic (Xiao et al. 2018) and non-calcifying, so for it to form a benthic complex calcified mass, it is necessary to explain how it could accumulate to form a framework with constructed cavities, and no obvious mechanism is demonstrated for modern planktonic bacteria. Furthermore, Wu et al. (2016) interpreted the PTBM recrystallized form as representing fossilized representatives of the modern cyanobacterium Stanieria, although similarity of form is not proof of affinity; also Stanieria occurs as spheres (Wu et al. 2016, Fig. 4), and does not develop irregular outlines, in contrast to the greater variability of form of blobs in $C$. wangshenghaia. We also note that Tarthinia has been described from only Cambrian-age rocks, it is absent in later strata so the similarity between Tarthinia and Calcilobes is remarkable. The possibility exists that Calcilobes is a modified form of Tarthinia, that resurged after the largest mass extinction to form the extensive masses seen across the South China Block; whether that gives credence to the views of some authors that the post-extinction facies are anachronistic (Baud et al. 2007) remains an area for continuing debate.

If $C$. wangshenghaii formed originally as solid blobs of micritic/microsparitic material, then its function as calcimicrobe is in question; it is unlike the hollow filaments or sheaths that constitute, such calcimicrobes as Girvanella or Rivularia, for example, and thus draws attention to the possibility that $C$. wangshenghaii is comprised of microbially constructed sedimentary carbonate, not a calcimicrobe. Discriminating between these two possibilities depends on the original structure, so that classification of $C$. wangshenghaii suffers the same classification uncertainties as do Renalcis, Tarthinia, Epiphyton and other microbial genera.

The common partial alteration of solid micrite-microsparite to a structure with micritic-sparitic rims and sparite interiors also demands an explanation; why are the interiors seemingly more susceptible to recrystallisation than the rims? The answer may lie in the possibility that $C$. wangshenghaii formed by agglutination of micrite, so that the outer portion of the structure contained organic matter that partially protected it from alteration, in contrast to the interior of blobs.

Overall, because $C$. wangshenghaii lacks features which can be unequivocally linked to any microbial group, and partly because of the aggrading recrystallisation to sparite, its affinity remains open to interpretation. Nevertheless, $C$. wangshenghaii is interpreted here as organic, on the grounds of its morphology and preferential recrystallisation in contrast to the well-preserved micritic sediment in its interstices. Nevertheless, whether it was a bacterium or cyanobacterium or other organic structure is not known. Consequently, there is no supporting evidence that would demonstrate whether it was photosynthesizing or not, thus, interpretations of a cyanobacterial origin may or may not be correct. Nevertheless, interpretation that such similar structures as Tarthinia, Renalcis and Epiphyton may have been cyanobacteria is well known in literature (see discussions in Riding 2011b; Lee et al. 2014; Liu et al. 2016; Zhang et al. 2019), so do not preclude the option of a cyanobacterial nature for the $C$. wangshenghaii in the PTBMs. Implications for palaeo-environmental reconstructions are obvious and will need further work to determine this aspect.

Finally, it may be argued that because areas of the thrombolitic structure are so strongly recrystallized that all internal structure is lost, there is a question as to whether other components were present in the microbialite construction, that are not preserved. Such a situation may be difficult to verify, but a key point is that wherever structure is observed, it has the lobate morphology in all cases, and provides confidence that the microbialite (apart from the uncommon stromatolites) was built by a single microbial taxon. That would be remarkable given its large areal extent across the South China Block, noting that Cambrian occurrences of similar microbial forms (e.g. Lee et al. 2014) are composed of numerous microbial genera occurring adjacent to each other.

\section{Mineralogy}

C. wangshenghaii occurs with ostracods, molluscs and other fossils that accumulated in the matrix between microbial branches, and uncommonly within the microbialite structure (e.g., Yang et al. 2011). Ostracods are low-magnesium calcite (LMC) and are consistently very well preserved; in contrast, molluscs are consistently preserved as sparite infills of moulds indicating either solution then sparite infilling, or recrystallisation to sparite, hence reflecting their original aragonitic composition. C. wangshenghaii, however, is normally partly preserved with micritic rims and sparite interiors (hence the prior Renalcis-like attribution as discussed above), but in places where it is strongly recrystallized, the structure is represented by large calcite crystals. In some cases, there are inclusions of small rhombohedral carbonate that does not stain with Alizarin Red S, attributed to dolomite (not illustrated here, see Ezaki et al. 2008, Fig. 8D). The textural discrimination between preservation 

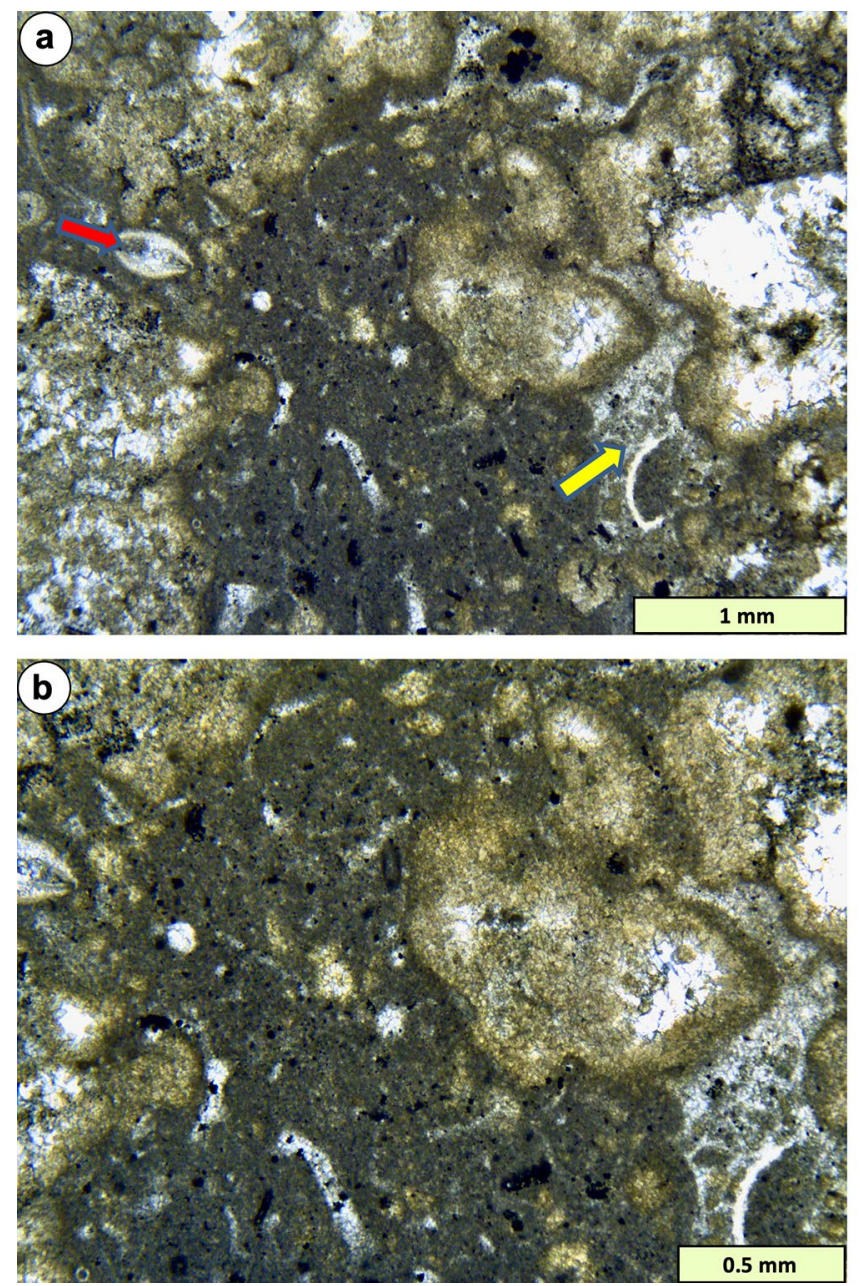

Fig. 5 a Enlargement of upper box in Fig. 4, showing vertical section of details of lobate fabric of holotype of $C$. wangshenghaii. The lobate microbial structure is composed of microsparitic outer parts grading to recrystallised sparite in the interior parts. Yellow arrow highlights that the matrix has a clotted aspect because of an uneven-shaped cavity filled with small peloids, bioclasts and cement. Note articulated ostracod carapace centre left (red arrow). b enlarge-

of $C$. wangshenghaii in contrast to LMC and original aragonite shells provides an argument that $C$. wangshenghaii was formed originally of high-magnesium calcite (HMC), with the magnesium being released during diagenesis to form dolomite, following the arguments presented by Lohmann and Meyers (1977). However, in the case of $C$. wangshenghaii, dolomite rhombs occur sporadically within the microbial carbonate and surrounding matrix, so there is not a consistent link. This situation is a curious parallel to the preservation of (unrelated) Palaeozoic stromatoporoid sponges, which may have been HMC (Kershaw et al. 2021), but also unverified, partly due to a similar inconsistency of distribution of microdolomite rhombs.

Other investigations may aid the interpretation of $C$. wangshenghaii. Cathodoluminescence (CL) images (Zhang

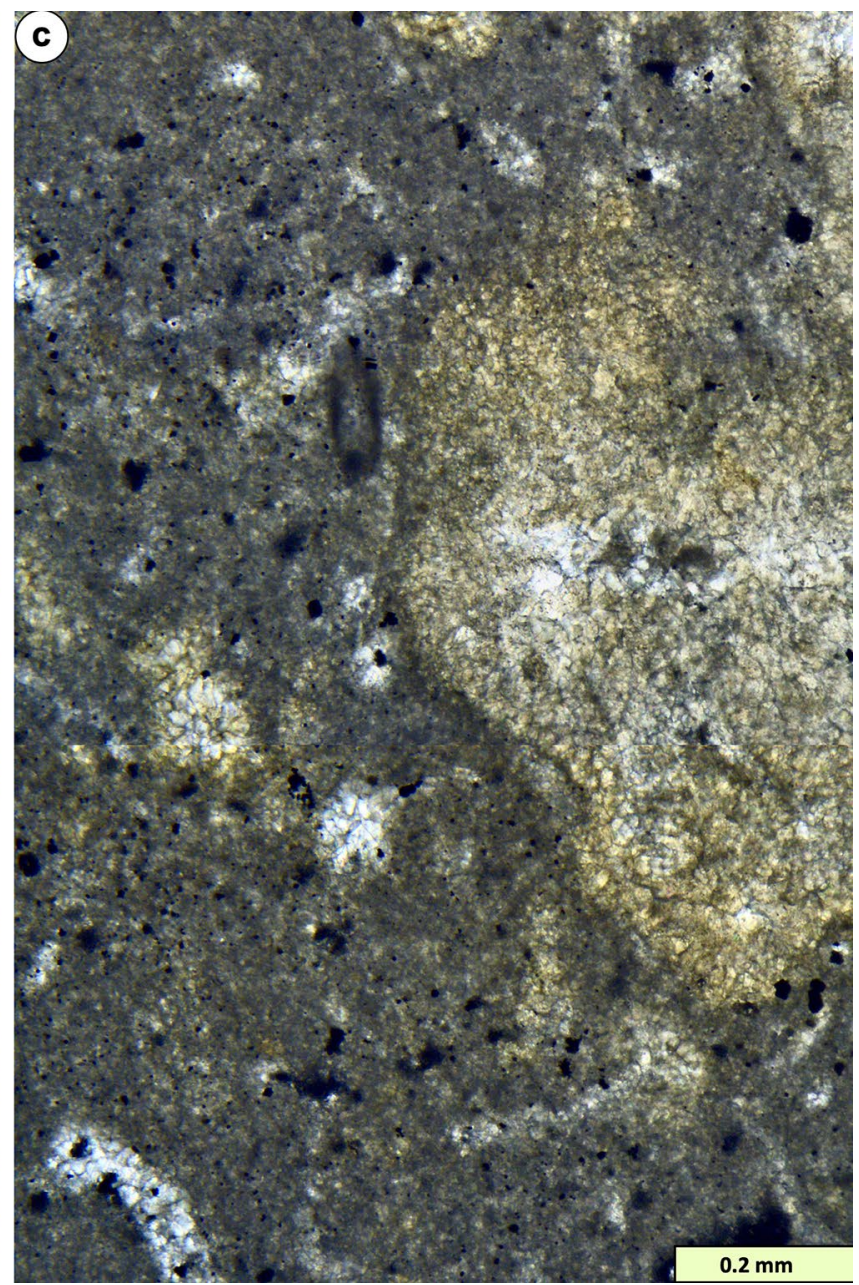

ment of central part of a, emphasising the partly recrystallised nature of lobate fabric, clotted micrite matrix, cavity and bioclasts. c Enlargement of centre of $\mathbf{b}$ showing micritic-microsparitic nature of lobate fabric undergoing incipient alteration. Centre-left is a small area of identical fabric that may be either an individual blob of $C$. wangshenghaii or a fortuitous cross section through the margin of the framework in section parallel to the plane of the photograph

et al. 2021, Fig. 7) show the micritic matrix has the same dull CL response as the micritic portions of the microbial material, contrasting the sparitic areas of the microbial structure, which are more brightly luminescent. This contrast is consistent with our interpretation that the micritic areas are close to the original microbial material, while the sparitic areas are recrystallized (probably in early diagenesis below the redox boundary) to form brightly luminescing portions. Stable carbon and oxygen isotope work (e.g., Mu et al. 2009; Zhang et al. 2021) show the microbial branches have similar ratios to the adjacent sediment, evidence that the microbial structure formed in equilibrium with ambient seawater, but such evidence does not aid determination of the nature of the structure, since many organisms precipitate calcium carbonate in equilibrium with seawater. SEM studies have revealed 

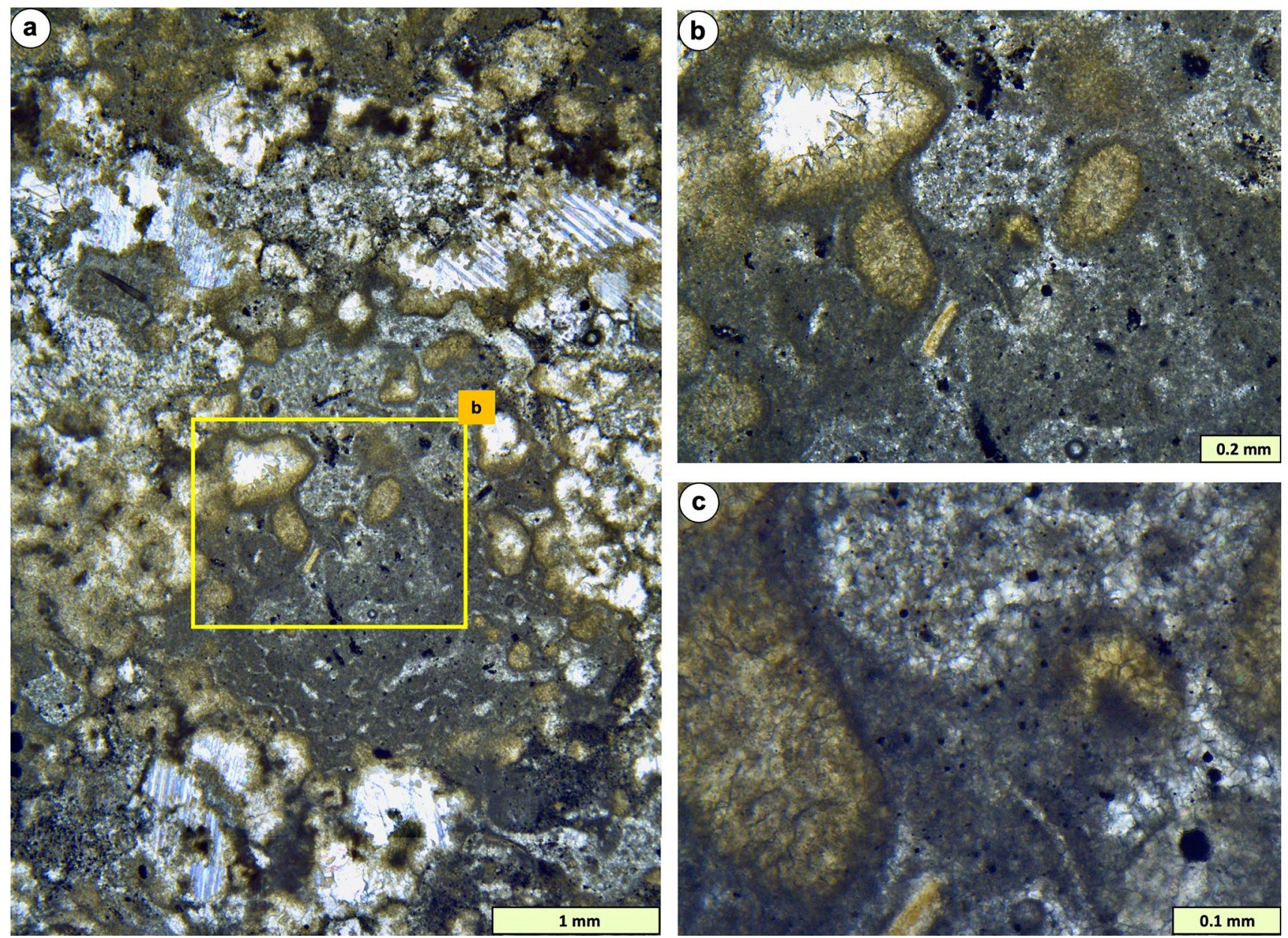

Fig. 6 a Enlargement of lower box in Fig. 4, showing vertical section of details of lobate fabric of holotype of $C$. wangshenghaii. $\mathbf{b}$, c Enlargement of box in a, showing variable preservation of lobate fabric, part of which is better preserved (light brown areas with dark micritic rims). b, $\mathbf{c}$ also show clotted micrite is the first partial fill of space in the microbial frame, with small peloids and fine sparite filling remaining space; these images provide evidence that the lobate microbial structure was less stable in diagenesis than the fills little so far, only that the structure is recrystallized (e.g. Wu et al. 2017). As stated above, the solid fine-grained structure opens the question as to how it would have functioned as a calcimicrobe, since it lacks chambers and presumably did not contain internal organic tissue in the same sense that cyanobacteria do. Consequently, the construction of $C$. wangshenghaii remains enigmatic, perhaps appropriate to the unusual conditions immediately after the end-Permian extinction! Nevertheless, the distinctness of its structure, in contrast to other microbial-type structures, strengthens our view that it merits designation as a new microbial taxon. $C$. wangshenghaii occurs along with stromatolites (lacking the lobate texture) in some places, which implies that they were constructed by different processes, and thus likely different organic constructors.

\section{Individual blobs of $C$. wangshenghaii}

The larger peloids shown in Figs. 7 and 8 commonly have centres that have undergone alteration to microsparite, identical in thin section to the adjacent lobate framework. Peloids 

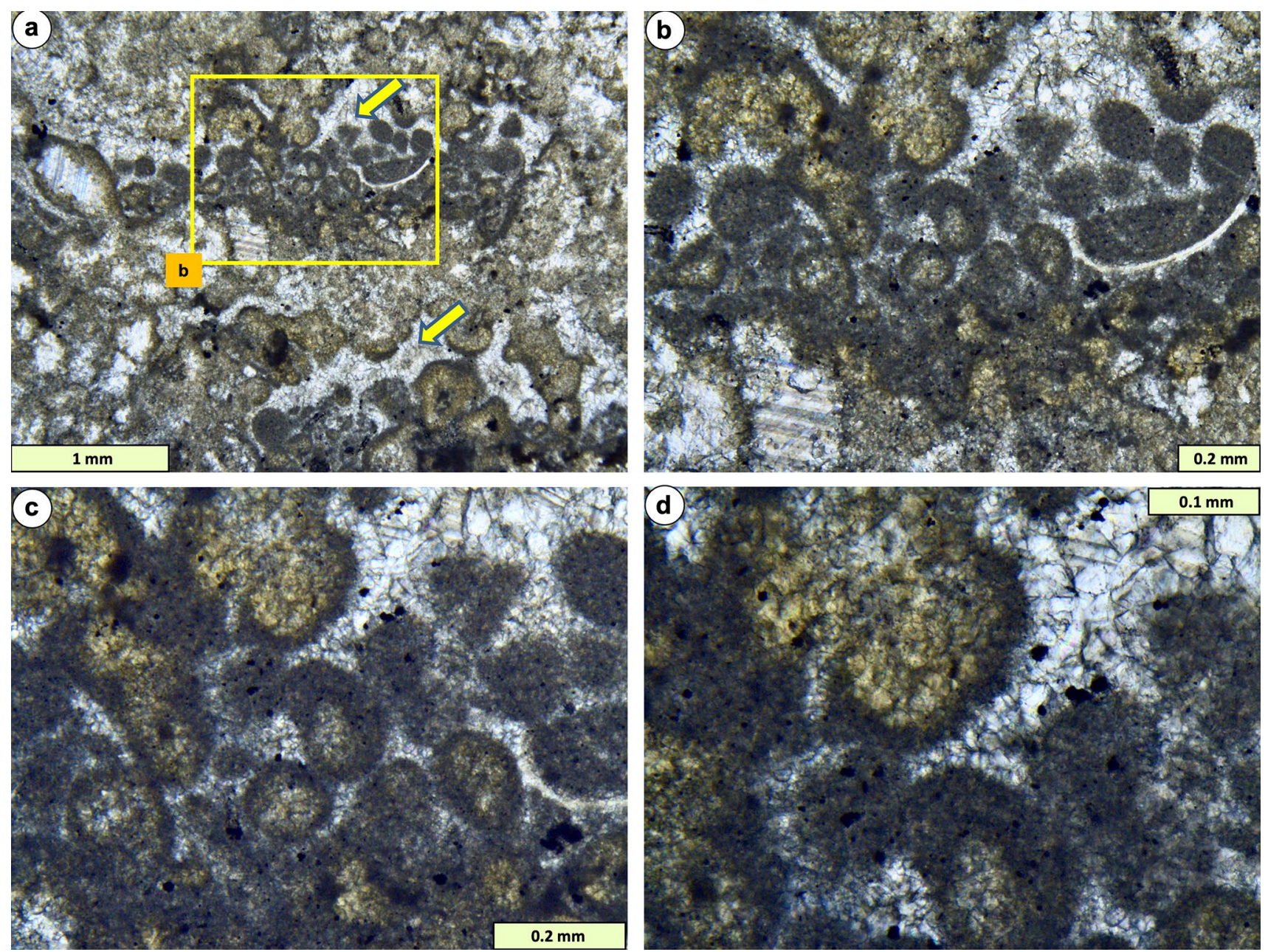

Fig. 7 Microbial framework of holotype of $C$. wangshenghaii in vertical section. a Partly recrystallised lobate microbial material with two small cavities (arrows), containing geopetal peloidal fills. b-d Enlargements of the upper cavity in a, showing that the peloids in the cavity are partly altered in the same style as the lobate microbial fabric, creating the impression that the peloidal objects may be the precursors of lobate framework development, here forming as slightly

in the matrix in Fig. 8 may be tangential sections through margins of microbial branches that lie out of the plane of the thin sections, but those in Fig. 7 are more reasonably viewed as being particulate fills in cavities in the microbialite. Peloids are generally recognized to be uniform solid objects (Burne and Moore 1987; Scoffin 1987; Tucker and Wright 1990) and those that have internal structure are generally considered to be highly micritized bioclasts (Adams and MacKenzie 2001). Peloids in Fig. 8, and maybe Fig. 7, however, are best explained by alteration of their interiors from an original solid micritic structure. The similarity between these peloids and the $C$. wangshenhaii fabric, and the difference between these peloids and the normal appearance of peloids, raises the question about the nature of these particular peloids within the framework. A similar later deposition, washed into cavities, after the main framework had grown. Thus $C$. wangshenghaii may have formed as round blobs of micrite that amalgamated into a framework, and in this case, some later blobs were deposited within cavities in the framework, while it was still on the sea floor, open to water circulation; see text for discussion

point emerges from examination of Fig. 9 that illustrates material from another site, showing gradations within the matrix fill, from unstructured micrite to a clotted form, in close association with the lobate form of $C$. wangshenghaii. Thus, we theorise that the peloids in Fig. 8 (and possibly Fig. 7) and the clotted micrite in Fig. 9, are the first stage of development of lobate microbia of $C$. wangshenghaii and may reflect microbial agglutination of micrite to form the blobs on the post-extinction sea floor. The characteristic of the cavity-filling peloids in Fig. 8, together with the individual lobate objects found in interstices in the framework, may be explained if $C$. wangshenghaii blobs formed initially as individual approximately spherical objects on the sea floor, that accumulated and merged to grow into a framework with cavities (see reconstruction in Fig. 10c). Some cavities then 

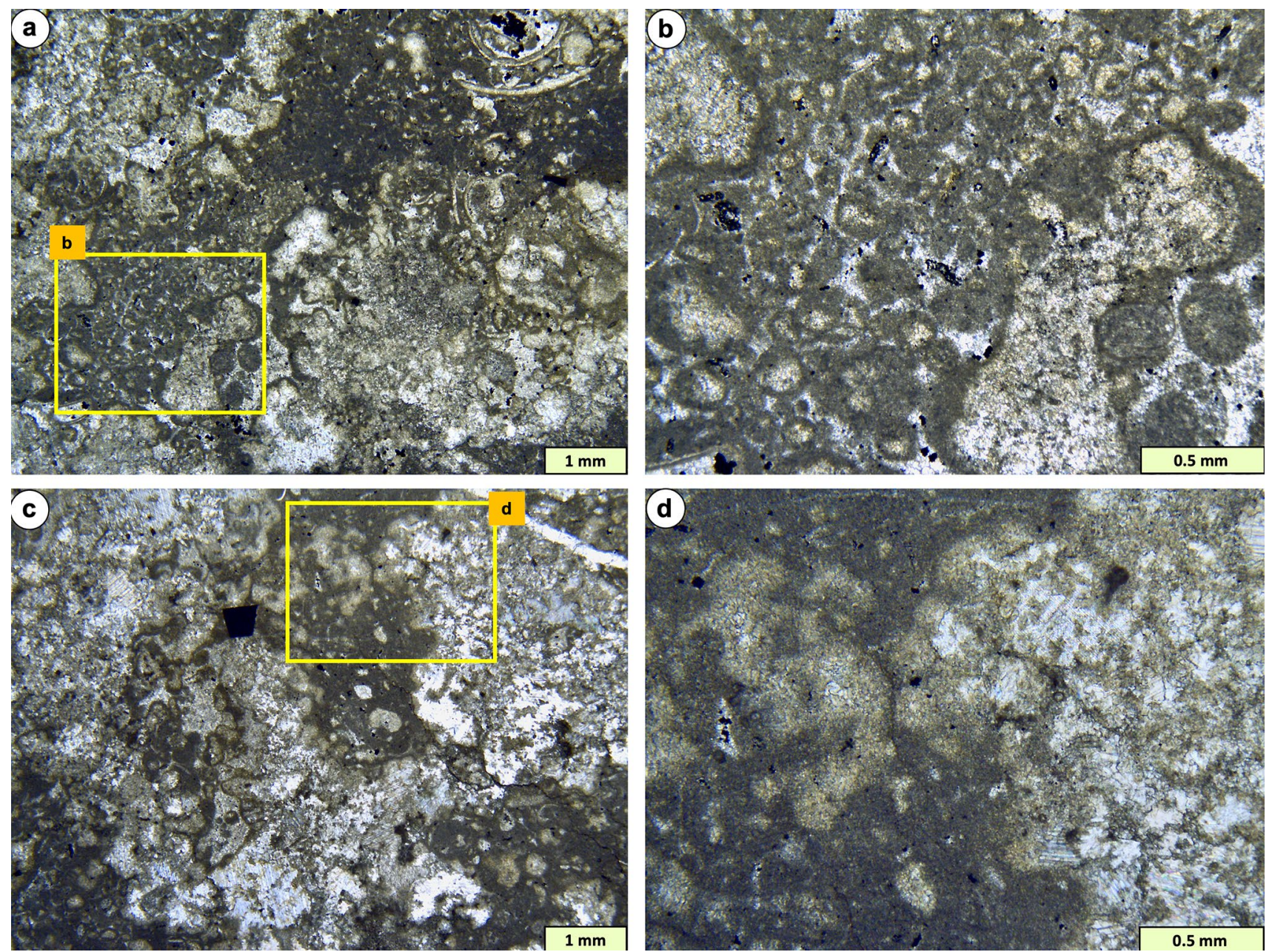

Fig. 8 Paratype specimen of $C$. wangshenghaii, showing transverse thin-section views. $\mathbf{a}, \mathbf{b}$ (b is enlargement of box in $\mathbf{a}$ ) partly recrystallised lobate framework, with cavity occupied by peloids that have undergone partial alteration to leave micritic rims and recrystallised interiors. c, $\mathbf{d}$ ( $\mathbf{d}$ is enlargement of box in c) lobate framework, partly recrystallised, with micritic matrix filling the cavity in the lobate

received further blobs washed in by currents, accounting for their presence in examples such as in Figs. 7, 8.

\section{Distribution}

C. wangshenghaii reported here occurs throughout shallow marine sequences in the South China Block, located in eastern Tethys Ocean (Fig. 1). However, a lobate microbialite is known from one site in NW Iran (western Tethys)

framework. Partial alteration of discrete small patches visible in the micritic fill may be sections through margins of lobes in transverse section, although instead may be evidence of partial alteration of clotted fill in the same style as the $C$. wangshenghaii microbial architecture

(Maaleki-Moghadam et al. 2019). Also, some samples from Çürük Dag in Turkey have remnant lobate fabric in material that is otherwise thrombolitic (SK unpublished observations of recently processed material). Otherwise PTBMs in western Tethys are substantially different from the South China Block. Given the interpreted ocean circulation (Fig. 1a) of Tethys, the differences between western and eastern Tethyan areas are unexplained. Further work is needed to fully assess these western Tethyan features, outside the scope of this study. 

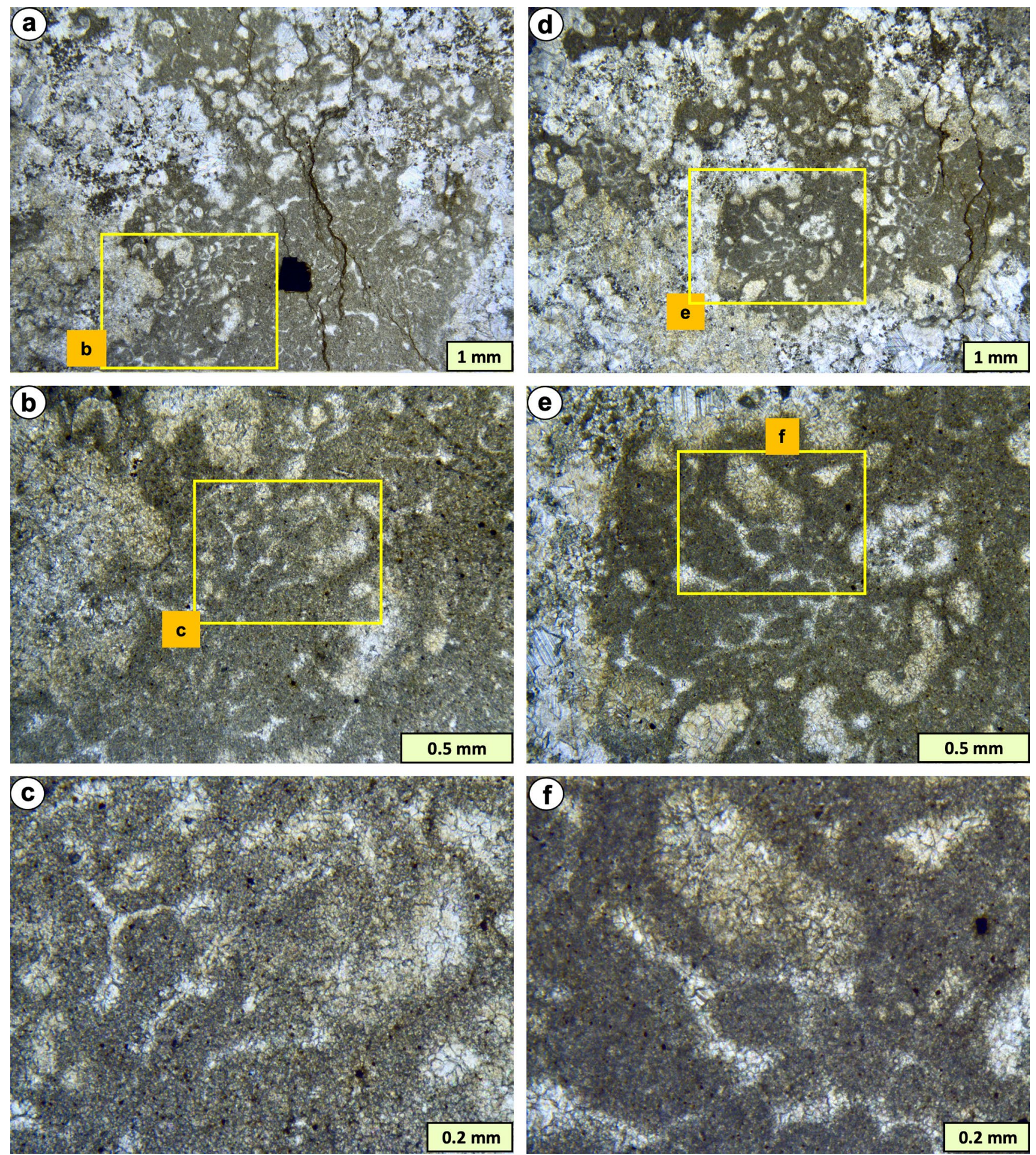

Fig. 9 C. wangshenghaii branch margin, from another sample, not holotype or paratype, with associated clotted micrites that form the matrix in some areas of the microbialite. a Vertical section showing largely recrystallised microbial branches left and right, with clotted micrite between. The clotted micrite contains apparent individual $C$. wangshenghaii blobs, partly altered, surrounded by micritic clots that show gradation to unclotted micrite in central lower part of image,

adjacent to the pyrite crystal (opaque). b, c Enlargements of box in a, showing clotted micrite adjacent to partly altered $C$. wangshenghaii blobs. d-f Another thin section from the same specimen as a-c, showing further examples of the same fabrics, of $C$. wangshenghaii and clotted micrites in the matrix. See text for discussion. Baizhuyuan site, northern Sichuan (see Kershaw et al. 1999, for locality details) 

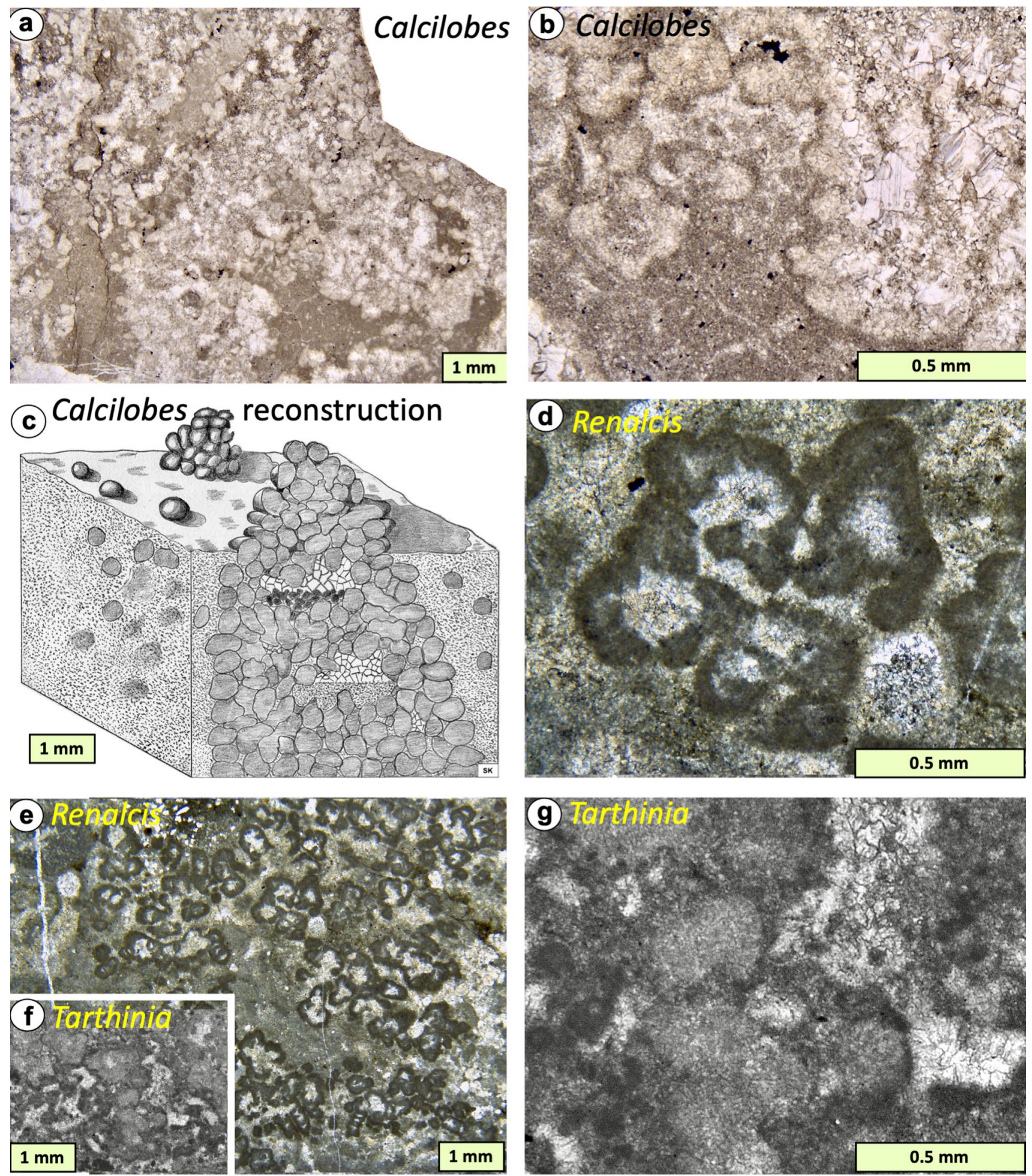

Fig. 10 C. wangshenghaii microbial architecture and renalcid fossils, compared, at the same scales. a, b (b is enlargement of lower central part of a) Vertical thin section of another sample of $C$. wangshenghaii (not the holotype or paratype), ground to a thinner slice than Figs. 3, 4, 5, 6, 7, showing variation of preservation; in $\mathbf{b}$, microsparitic structure is seen on the left half of the image, with recrystallised to sparite with microsparitic rims on the right half. Baizhuyuan site, northern Sichuan. c Schematic 3D reconstruction of growth style

of $C$. wangshenghaii, including lobate fabric and individual blobs in the sediment. d, e Renalcis from patch reef, Xiannüdong Formation, Cambrian, Tiangjiahe, northern Sichuan, China (sample provided by Hao Tang). f, g Tarthinia, Cambrian, Zhushadong Formation, Cambrian, Sunmayu section, central Shandong Province, China (image provided by Jeong-Hun Lee, see Lee et al. (2014). These images show the structure of Renalcis and Tarthinia differs from $C$. wangshenghaii 


\section{Conclusion}

1.. The principal constructor of Permian-Triassic Boundary Microbialites (PTBMs) in the South China Block is a framework interpreted to have been composed originally of micritic-microsparitic carbonate forming a unique microbial growth that has a lobate architecture, here formalized as a new microbial taxon Calcilobes wangshenghaii $\mathrm{n}$. gen, $\mathrm{n}$. sp. The framework is developed in layers and domes to construct extensive microbial biostromes in the South China Block; another constructing component is agglutinated stromatolite (lacking the lobate fabric) in some localities, in some cases forming in close proximity to $C$. wangshenghaii, and thus interpreted as constructed by a different process.

2. Discrete subspherical blobs of similar micritic-microsparitic material within cavities and within the matrix micrite between branches of $C$. wangshenghaii may be evidence of early formation of blobs of the microbial structure on the sea floor, that amalgamated to form the framework biostromes abundant in South China after the mass extinction.

3. C. wangshenghaii commonly shows gradational recrystallization to sparite, and in some places is sporadically dolomitized. In contrast, the micritic matrix in which $C$. wangshenhaii formed is normally unaltered, evidence that $C$. wangshenghaii was composed of an original mineralogy different from the matrix in which it is found. Ostracod shells (low-magnesium calcite) are better preserved and molluscs (originally aragonite) are poorly preserved, thus are fabric indicators that $C$. wangshenghaia may have had an original high magnesium calcite mineralogy. However, this is not corroborated by the sporadic pattern of dolomitization.

4. Similarity between $C$. wangshenghaii and comparable microbial taxa composed of micritic structure (in particular Renalcis, Tarthinia and Epiphyton) emphasizes the problem of classification of such microbial structures, leading to uncertainty as to whether $C$. wangshenghaii should be considered a calcimicrobe or a microbial sediment structure.

5. C. wangshenghaii dominates the post-extinction microbialites in the South China Block, and is known from only two other isolated occurrences, both in western Tethys (NW Iran and Turkey); reasons for this palaeogeographic limitation are unknown.

Acknowledgements We thank Xinan Mu (Nanjing), Jiasong Fan (Beijing), Hao Tang (Chengdu), the late Yongbiao Wang (Wuhan), Xiyang Zhang (Guangzhou), Pierre-Yves Collin (Dijon), Sylvie Crasquin and Marie-Béatrice Forel (Paris) for discussions of microbialites; and
Simon Schneider (CASP, UK) for advice on taxon naming. We thank Jeong-Hyun Lee (Daejeon) and Hao Tang (Chengdu) for photographs of Tarthinia and Renalcis respectively. We are grateful to Juebo Wang for providing background information regarding her father Shenghai Wang. TZ was supported by National Nature Foundation of China grant \# 41272135; and YL was supported by Strategic Priority Research Program of Chinese Academy of Sciences, Grant No. XDB26000000.

Funding See Acknowledgements.

Availability of data and material Not applicable.

Code availability (software application or custom code) Not applicable.

\section{Declarations}

Conflict of interest Not applicable.

Open Access This article is licensed under a Creative Commons Attribution 4.0 International License, which permits use, sharing, adaptation, distribution and reproduction in any medium or format, as long as you give appropriate credit to the original author(s) and the source, provide a link to the Creative Commons licence, and indicate if changes were made. The images or other third party material in this article are included in the article's Creative Commons licence, unless indicated otherwise in a credit line to the material. If material is not included in the article's Creative Commons licence and your intended use is not permitted by statutory regulation or exceeds the permitted use, you will need to obtain permission directly from the copyright holder. To view a copy of this licence, visit http://creativecommons.org/licenses/by/4.0/.

\section{References}

Adachi N, Asada Y, Ezaki Y, Liu JB (2017) Stromatolites near the Permian-Triassic boundary in Chongyang, Hubei Province, South China: a geobiological window into Palaeo-oceanic fluctuations following the end-Permian extinction. Palaeogeogr Palaeoclimatol Palaeoecol 475:57-69

Adams AE, MacKenzie WS (2001) A colour atlas of carbonate sediments and rocks under the microscope. Manson Publishing, London, p 180

Baud A, Richoz S, Marcoux J (2005) Calcimicrobial cap rocks from the basal Triassic units: western Taurus occurrences (SW Turkey). CR Palevol 4:569-582

Baud A, Richoz S, Pruss S (2007) The lower Triassic anachronistic carbonate facies in space and time. Glob Planet Change 55:81-89

Baud A, Richoz S, Brandner R, Krystyn L, Heindel K, Mohtat T, Mohtat-Aghai P, Horacek M (2021) Sponge takeover from endPermian mass extinction to early Induan time: records in central Iran microbial buildups. Front Earth Sci 9:586210. https://doi.org/ 10.3389/feart.2021.586210,23pages

Burne RV, Moore LS (1987) Microbialites: organosedimentary deposits of benthic microbial communities. Palaios 2:242-254

Esteban M, Klappa CF (1983) Subaerial exposure. Pp1-95 In Scholle PA, Bebout DG, Moore CH (eds) Carbonate depositional environments. AAPG Memoir 33, Tulsa, Oklahoma

Ezaki Y, Liu JB, Adachi N (2003) Earliest Triassic microbialite microto megastructures in the Huaying area of Sichuan Province, South China: implications for the nature of oceanic conditions after the end-Permian extinction. Palaios 18:388-402 
Ezaki Y, Liu JB, Nagano T, Adachi N (2008) Geobiological aspects of the earliest Triassic microbialites along the southern periphery of the tropical Yangtze Platform: initiation and cessation of a microbial regime. Palaios 23:356-369

Foster WJ, Heindel K, Richoz S, Gliwa J, Lehrmann DJ, Baud A, Kolar-Jurkovšek T, Aljinović D, Jurkovšek MB, Korn D, Martindale RC, Peckmann J (2019) Suppressed competitive exclusion enabled the proliferation of Permian/Triassic boundary microbialites. Depos Rec 6:62-74

Friesenbichler E, Richoz S, Baud A, Krystyn L, Sahakyan L, Vardanyan S, Peckmann J, Reitner J, Heindel K (2018) Sponge-microbial build-ups from the lowermost Triassic Chanakhchi section in southern Armenia: microfacies and stable isotopes. Palaeogeogr Palaeoclimatol Palaeoecol 490:653-672

Hughes GW (2013) Late Permian to Late Jurassic "microproblematica" of Saudi Arabia: possible palaeobiological assignments and roles in the palaeoenviromental reconstructions. GeoArabia 18:57-92

Kershaw S (2015) Modern Black Sea oceanography applied to the endPermian extinction event. J Palaeogeogr 4:52-62

Kershaw S, Zhang TS, Lan GZ (1999) A ?microbialite carbonate crust at the Permian-Triassic boundary in South China, and its palaeoenvironmental significance. Palaeogeogr Palaeoclimatol Palaeoecol 146:1-18

Kershaw S, Li Y, Crasquin-soleau S, Feng Q, Mu X, Collin P-Y, Reynolds A, Guo L (2007) Earliest Triassic microbialites in the South China Block and other areas: controlson their growth and distribution. Facies 53:409-425

Kershaw S, Crasquin S, Li Y, Collin P-Y, Forel M-B (2012) Ocean acidification and the end-Permian mass extinction: to what extent does evidence support hypothesis? Geosciences 2:221-234. https://doi.org/10.3390/geosciences2040221

Kershaw S, Munnecke A, Jarochowska E, Young G (2021) Palaeozoic stromatoporoid diagenesis: a synthesis. Facies 67:43. https://doi. org/10.1007/s10347-021-00628-x

Lee JH, Lee HS, Chen J, Woo J, Chough SK (2014) Calcified microbial reefs in Cambrian Series 2, North China Platform: Implications for the evolution of Cambrian calcified microbes. Palaeogeogr Palaeoclimatol Palaeoecol 403:30-42

Lehrmann DJ (1999) Early Triassic calcimicrobial mounds and biostromes of the Nanpanjiang Basin, South China. Geology 27:359-362

Liu L, Wu Y, Yang H, Riding R (2016) Ordovician calcified cyanobacteria and associated microfossils from the Tarim Basin, northwest China: systematics and significance. J Syst Palaeont 14:183-210. https://doi.org/10.1080/14772019.2015.1030128

Lohmann KC, Meyers WJ (1977) Microdolomite inclusions in cloudy prismatic calcites - a proposed criterion for former high-magnesium calcites. J Sediment Pet 42:1078-1988

Maaleki-Moghadam M, Rafiei B, Richoz S, Woods AD, Krystyn L (2019) Anachronistic facies and carbon isotopes during the endPermian biocrisis: evidence from the mid-Tethys (Kisejin, Iran). Palaeogeogr Palaeoclimatol Palaeoecol 516:364-383

Mu X, Kershaw S, Li Y, Guo L, Qi Y, Reynolds A (2009) High-resolution carbon isotope changesin the Permian-Triassic boundary interval, Chongqing, South China; implications for control and growth of earliest Triassicmicrobialites. J Asian Earth Sciences 36:434-441

Pratt BR (1984) Epiphtyon and Renalcis-diagenetic microfossils from calcification of coccoid blue-green algae. J Sediment Pet 54:0948-0971
Pruss SB, Bottjer DJ, Corsetti FA, Baud A (2006) A global marine sedimentary response to the end-Permian mass extinction: examples from southern Turkey and the western United States. Earth Sci Rev 78:193-206

Reinhardt JW (1988) Uppermost Permian reefs and Permo-Triassic sedimentary facies from the southeastern margin of the Sichuan Basin, China. Facies 18:231-286

Riding R (2011a) Microbialites, stromatolites and thrombolites. In: Reitner J, Thiels V (eds) Encyclopedia of geobiology. Encyclodpedia of earth science series. Springer, Heidelberg, pp 625-654

Riding R (2011b) Calcified cyanobacteria. In: Reitner J, Thiels V (eds) Encyclopedia of geobiology. Encyclodpedia of earth science series. Springer, Heidelberg, pp 211-223

Scoffin TP (1987) Carbonate Sediments and Rocks. Blackie; Glasgow and London, 274pp.

Stephens NP, Sumner DY (2002) Renalcids as fossil biofilm clusters. Palaios 17:225-236

Tucker ME, Wright VP (1990) Carbonate Sedimentology. Blackwell Scientific Publications, Oxford and London, p 482

Wang S, Qiang Z, Wen Y, Tao Y (1994) Petrology and origin of the calcareous crusts capping the Permian reefs in Huaying Mountains, Sichuan, China. J Miner Pet 14:59-68

Wu YS, Yu GL, Li RH, Song LR, Jiang HX, Riding R, Liu LJ, Liu DY, Zhao R (2014) Cyanobacterial fossils from 252 Ma old microbialites and their environmental significance. Sci Rep 4:3820. https:// doi.org/10.1038/srep03820

Wu YS, Yu GL, Jiang HX, Liu LJ, Zhao R (2016) Role and lifestyle of calcified cyanobacteria (Stanieria) in Permian-Triassic boundary microbialites. Palaeogeogr Palaeoclimatol Palaeoecol 448:39-47

Wu S, Chen ZQ, Fang YH, Pei Y, Yang H, Ogg J (2017) A PermianTriassic boundary microbialite deposit from the eastern Yangtze Platform (Jiangxi Province, South China): Geobiologic features, ecosystem composition and redox conditions. Palaeogeogr Palaeoclimatol Palaeoecol 486:58-73

Xiao M, Li M, Reynolds CS (2018) Colony formation in the cyanobacterium Microcystis. Biol Rev 93:1399-1420

Xie S, Pancost RD, Wang Y, Yang H, Wignall PB, Luo G, Jia C, Chen L (2010) Cyanobacterial blooms tied to volcanism during the 5 m.y. Permo-Triassic biotic crisis. Geology 38:447-450

Yang H, Chen ZQ, Wang Y, Tong JN, Song H, Chen J (2011) Composition and structure of microbialite ecosystems following the end-Permian mass extinction in South China. Palaeogeogr Palaeoclimatol Palaeoecol 308:111-128

Zhang XY, Dai M, Wang M, Qi YA (2019) Calcified coccoid from Cambrian Miaolingian: revealing the potential cellular structure of Epiphyton. PLoS ONE. https://doi.org/10.1371/journal.pone. 0213695

Zhang XY, Wang Q, Yuan DX, Zhang H, Zheng QF (2020a) Stromatolite-dominated microbialites at the Permian-Triassic boundary of the Xikou section on South Qinling Block, China. Paleoworld $29: 126-136$

Zhang XY, Zheng QF, Li Y, Yang HQ, Zhang H, Wang WQ, Shen SZ (2020b) Polybessurus-like fossils as key contributors to PermianTriassic boundary T microbialites in South China. Palaeogeogr Palaeoclimatol Palaeoecol 552:109770

Zhang XY, Li Y, Wang G, Yang HQ (2021) Different accretion and diagenetic patterns within the fabrics of the Permian-Triassic boundary microbialites on the Leye isolated carbonate platform South China Block. J Palaeogeogr. https://doi.org/10.1186/ s42501-021-00091-3 